\title{
Education Reform of International Trade Major to Obtain Employment
}

\author{
Dao Zhou
}

Hunan International Business Vocational College, Changsha, 410201, China

\author{
Keywords: International Trade Major, Obtain Employment, Orientation, Education reform
}

\begin{abstract}
With the eruption of international financial crisis, there are many changes happened to the international trade. At the same time, because of the recruitment expansion of universities in recent years, employment of international trade major is not optimistic. This asks universities and colleges to make reforms to help students improve their adaptive capacity in the fierce employment competition. For example, colleges needs to know the standards of company, increase the practice of students, change the teaching content, and improve the quality of students.
\end{abstract}

\section{Introduction}

For the influence of financial crisis and the European debt crisis, the world economic is recession, and the economy of our country's export markets also slide down, which brings negative impact on China's exports. At the same time, the demand of international trade for talents is also shrinking. The obtain employment of international trade major is not optimistic.

\section{The importance of teaching reform for international trade major}

International trade is studying at financial and economic. Due to the strong discipline of knowledge structure, and the guidance for foreign investment and cash flows, the unity of the international trade social organic will promote the growth of the national economy. Therefore, universities must intensify the teaching reform of international trade professional course during its development talent who is good at economic. The goal of fostering talents in universities is promoting the comprehensive ability of students that will good for the promoting of students' employments. So under the influence of many factors for professional international trade, the quality of teaching needs to be improved. For the teaching reform of international trade major, the link between teaching and practice, and the guidance of employment is not only improving the teaching goal, but also improve the comprehensive capacity of students, which will increase the employment rate. Then the severe employment pressure will be slow down, and our economic will be increasing more rapidly. In short, the teaching reform of international trade major has a great effect on improving students' employment and economic growth.

\section{Investigation content of international trade major's employment direction}

\section{Foreign trade}

Name of this type of employment is variable in different companies, such as foreign trade salesman, international trade coordinator and export sales and so on, but the basic direction of this type of job is the same, mainly to explore customer in the international market, deal with international trade related work by telephone or ectotheca. This requires graduates to have strong communication ability and explore ability, English is basic tool when communicate with foreign customers, thus needs strong basic English skills of the graduates.

\section{Customs clearance, quarantine inspection, forwarder}

These positions have no strict requirement on the education background, but they have their own threshold, that is customs declaration certificate or inspection certificate and other professional qualification certificates. For some small companies, many positions are not very professional, that 
needs graduates with some basic knowledge on the operation of foreign trade documents, requirements for graduates in the international trade major is relatively higher.

\section{Translation and other international business negotiation}

International trade major has a relatively higher requirement on English, graduates of this major take their advantages to find jobs relate to English, like translation or interpretation. This kind of companies have a relatively high requirements on graduates' oral English, some companies even require two foreign languages and the understanding of international trade knowledge.

\section{Primary financial jobs}

Courses of international trade are close to courses of financial majors, normally includes international settlements, international trade, international insurance and other related courses. It is very similar to the requirements of bank and financial institutions, meanwhile, graduates in international trade major have a strong ability of foreign language, so primary financial jobs also become their first choice.

\section{Problems existing in the courses design of international trade major in China \\ Problems of course setting}

At present, international trade major is in the development process without desired result, which makes teaching of this major in a passive situation. Firstly, before setting courses, the position of this major is not right, which leads to the foreign trade talents have no strong comprehensive ability, further to affects their integrated development. There are contradiction between the cultivation of foreign trade talents and English talents in the international trade major, which leads to the inadequacy of professional knowledge, and haven't connected organically with the market demands, make graduates face many challenges in their position. Secondly, course setting of the international trade major is inconsistent with the university requirements, which leads to the function of universities cannot play effectively. Students' knowledge structure has no characteristics, international trade talents cannot meet social requirements, thus graduates in this major face lots of challenges.

\section{Lack of practical course}

Though our education system is continuously reform and innovated, there are still many problems in the development process of college and universities. Course proportion of colleges and universities is not coordinate. For example, lack of practical courses but with lots of theoretical courses. Students are with much theoretical knowledge but lack of real operational ability, which leads to the defective of talents structure and cannot adjust to the social demands.At present, international trade major includes knowledge of trade, economy and English, pure theoretical knowledge learning cannot get good effect. Colleges and universities need to establish good relationship with enterprises to provide more practice opportunities for students. Though many colleges and universities arranged post-fixing practice, but the practice time is too short, and practice are also with strong theoretical knowledge, which cannot exercise students' actual operation ability.

Therefore, after the international trade graduates get into the position, their employment channel becomes narrow, hard employment is not for the development of society.

\section{Cooperation between colleges and enterprises is not enough}

At present, in order to have a better development, our country has to cultivate talents with comprehensive ability that can be qualified with the work of enterprises to relieve social employment pressure Therefore, colleges and universities must start from the real situation and improve every link in the teaching process of international trade major, not only do a good job in the theoretical teaching of international trade major, but also improve practical teaching, establish close relationship with enterprises to fully develop skills and comprehensive accomplishment of students in international trade major. However, in the actual work, cooperation between colleges and enterprises is not 
enough.There are flowing reasons for this phenomenon: Firstly, enterprises are not willing to pay more energy to cultivate international trade talent, they think this is full of risks and the cultivated talents may not meet their requirement, so they have little interest in the cooperation with colleges.Secondly, colleges need to pay lots of money to perfect construction of each link in the cooperation with enterprises, while some colleges are not willing to undertake this expense. Besides, when cooperated with enterprises, colleges will arrange teachers to make guidance, it will cost more manpower and material source, thus cooperation enthusiasm between colleges and enterprises will be reduced obviously, which will further influence their cooperation.

\section{Obsolete teaching content}

Rapid development of economy provides strong safeguards for the development of country. Meanwhile, acceleration of informatization process lays a good foundation for the development of economic society. Of course, in the process of international trade teaching, the obsolete teaching contents lead to students' incomplete knowledge structure, and cannot understand the new trends of social development, thus there is still a gap between their ability and the social demand.From China's entry into WTO, in order to get used to the international market, our national policy is always being adjusted, trying to reform economy and foreign system comprehensively to deal with international matters under the healthy trade system to promote our nation's economy growth.

However, under the changing policy and trading environment, the teaching materials of international trade major just changed a little, obsolete teaching materials makes the knowledge system is not brand new. Therefore, after students get into position, they need to take a long time to get used to the process and to learn relevant international trade under the new system. Therefore, this will lead to the deviation of teaching and employment.

\section{Specific strategies for the teaching reform of international trade specialty based on Employment}

\section{Increase the proportion of practical teching}

Under the function of constant reform on teaching system, colleges have to be employment-oriented, make reform for the international trade major to improve their employability. College education already change from the traditional "elite education" to "public education", but teaching mode of some colleges are still in the traditional way, which is already cannot meet the age's development. Colleges should go out to the enterprises, to investigate enterprise need what kind of people, refer to the enterprises' employment standard to cultivate students, complete teaching plan, change the traditional mode of emphasize theoretical.

Meanwhile, college can choose relevant teachers for advanced study according to their own situation to improve their basic skill and enrich practical teaching content. Reasonably increase practical courses, update the old teaching equipment to improve basic situation of the practical link.

\section{Improve the emphasis on optional courses}

In the traditional teaching, attention to the required courses are much more than that for optional courses, but with the severe situation of employment, requirements on the basic quality and ability is enhanced, thus needs colleges to extend students' knowledge. Optional courses places emphasis on the horizontal expand and longitudinal deepening, and motivate students' divergent thinking and logical thinking, and better to cultivate their creativity. Optional course can better meet students' interests, optimize their knowledge structure, to lay foundation for the cultivation of versatile talents and international-oriented talents.Pay attention to the setting and proportion of optional courses, let students make knowledge structure in the optional courses and enhance their employment ability.

\section{Teaching mode that emphasize certification}

Compared with other industries, foreign trade has low requirement on the graduates' education background, generally, junior college and bachelor can be qualified for relevant work, but with the same relevant knowledge, one with professional qualification certificates is easier to get a job. 
There are lots of certificates in the international trade major, such as customs declarer, inspection staff, international business documents are all the astepping-stone to success. This needs colleges to write the relevant information of certificates into the teaching plan, refer to relevant content of the certificate, increase lessons, provide knowledge storage for students to get relevant certificates, meanwhile, college can encourage students to get the certificate, to enhance their enthusiasm through favorable policy.

\section{Strengthen cooperation between colleges and enterprises}

College-enterprises cooperation is an important mode for the present colleges, talents cultivated by colleges can be accepted by the enterprise or not, is an important detection for their talents cultivation effects.

As a talents cultivation organization, colleges firstly need to know the society needs what kind of talents, then can cultivate talents accordingly. ooperation between college and enterprises can make colleges further to know the talent demands of enterprises. Enterprises need what kind of talents, graduates should with what kind of quality, all these can be realized by cooperation between college and enterprises.Colleges make corresponding courses and cultivating project according to the demands of enterprises. Through strengthen cooperation between college and enterprises, students' ability has been improved, and employment problems got an effective improvement; secondly, in the process of cooperation, personnel with rich experience in the enterprises can carry out training for students, teach them relevant experience and share them the new trend of trade, let the students combine theoretical knowledge with social practice, to form a complete knowledge framework in the brain to improve their comprehensive ability for international trade. Cooperation between college and enterprises can meet enterprises' talent demand, let the enterprise gain qualified talents in a very short time. Students can get practice opportunity through the cooperation, help them improve practical ability and occupational abilities, to have advantage in the fierce competitive employment market.

\section{Conclusion:}

In the modern society, employment is the basis, only students get a good employment, the social problem can be solved fundamentally. But there are still many inadequacies in the international trade teaching process.

For example, obsolete teaching content, low practicalness are all main reasons restrict the development of colleges. In order to stimulate the rapid development of economy, colleges must take employment-oriented as this principle in their teaching process, make reform on the teaching of international trade major to realize good employment of graduates of this major.

\section{Acknowledgments}

This paper is the project of the $12^{\text {th }}$ five-year plan of Education science in Hunan province, Research on the talents cultivation mode of of International Trade Major in vocational colleges.

\section{References}

[1] Zong Xueping. Teaching Mode and Ideas of Vocational English on the Basis of Emplyment-oriented. . Hei Longjiang Education (Research and Evluation of Higher Education). 2008(Z1)

[2] Jin Xizai, Zhu Zhiqiang. The Current Situation, Problems and Countermeasures of China's University Students’ Employment. Economic Aspect. 2005(01)

[3] Li Kexin, Zhang Xiaoli. Analysis on the Employment Prospect of International Trade Major. Chinese College Student Employment. 2004(Z2)

[4] Liu Hongyan. Exploration and Practice of the Teaching Reform of International Trade Major in Colleges. Vocational \& Technical Education Forum.2004(18) 
[5] Huang Dan, Lv dan. Research on the Teaching Reform of International Trade Major in the Private Higher Education Institution Based on Employment-oriented. Corporate Culture ,2015(6):262-263.

[6] Zheng Junrui, Li Hui. Problems and Countermeasures of Talents Cultivation of International Trade Major in the Vocational College. Education exploration,2013(8):107-108.

[7] Shiman. Discussion on English Class Teaching Mode of International Trade Major Based on Employment-oriented. Journal of Inner Mongonia Financial college,2011,09(6):68-70.

[8] Zhongjie. Research on Teaching of International Trade Major Based on Employment-oriented. Chinese and Foreigner Etrepreneurs,2015(5):271.

[9] He Yan. Personnel Opinions on the Teaching Reform Measures of International Trade Major Based on Employment-oriented. Farmer Science and Technology,2013(8):113-113,161. 